[49] 2011

\title{
TYPOMORPHIC FEATURES OF GROUNDMASS MINERALS FROM DIAMONDIFEROUS KIMBERLITES OF YAKUTIA
}

\author{
D.A. Yakovlev, S.I. Kostrovitsky, L.F. Suvorova \\ Institute of Geochemistry, Siberian Branch of Russian Academy of Sciences \\ 1A Favorsky Str., Irkutsk, 664033, Russia
}

\section{Introduction}

The Yakutian kimberlite province, occuring in the northeast of the Siberian platform, includes five industrial diamondiferous fields (listed below, as objects of this study except for the Nakynsky field). By present time the groundmass mineralogy of this kimberlite is has been insufficiently studied. However, some publications are available on the typical features of oxide minerals of the Yakutia kimberlites, e.g. Blagulkina et al., 1975; Kornilova et al., 1983; Verzhak et al., 1989; Bovkun, 1999, 2000, Krotkov et al., 2001; Garanin, 1984, 2009). More detailed studies have been conducted on the bulk minerals in the African and Canadian kimberlites, e.g. Haggerty et al., 1976; Boyd et al., 1977; Boctor et al., 1979; Dawson, 1980; Agee et al., 1982; Mitchell, 1986; Armstrong et al., 2004; Mitchell et al., 1998; Fedortchouk \& Canil, 2004; Roeder et al., 2008. They examined an issue related to the evolution of individual intrusive phases in the intricately built pipes (Shee, 1982; Hall et al., 1986; Salpas et al., 1986, etc.). Nevertheless, comprehensive studies of groundmass mineral typomorphism for the Yakutian kimberlite province have not been accomplished yet.

\section{Petrography and petrochemistry}

Kimberlites have been studied in the pipes: Internatsionalnaya, Mir, 23 KPSS - Malobotuobinsk field; Udachnaya, Zarnitsa - Daldyn field; Aikhal, Yubileinaya, Sytykanskaya - Alakit-Markha field; Zapolarnay Verhnemunsk field. Some texture-structural varieties of kimberlites have been recognized in this study (Fig. 1): porphyritic kimberlite (PK), kimberlite breccias (KB) and autolithic kimberlite breccia (AKB). KB characterized by different saturation xenoliths of country rocks (from $5 \%$ and more). AKB contains subrounded fragments of pre-existing solid igneous material and country rock xenoliths. PK is the rock of massive texture with country rocks less than $5 \%$, where macrocrysts occur in the groundmass (basis, matrix). The matrix minerals contain the second generation of euhedral primary olivine and/or phlogopite, together with perovskite, spinel, diopside, monticellite, apatite, sulfides, calcite, and primary late-stage serpentine. The grain size of groundmass minerals ranges from $0,005 \mathrm{~mm}$ to $1 \mathrm{~mm}$, most of them are euhedral. The most common are carbonate and serpentine, their contents varying from $10-50 \%$ and $20-70 \%$, respectively.
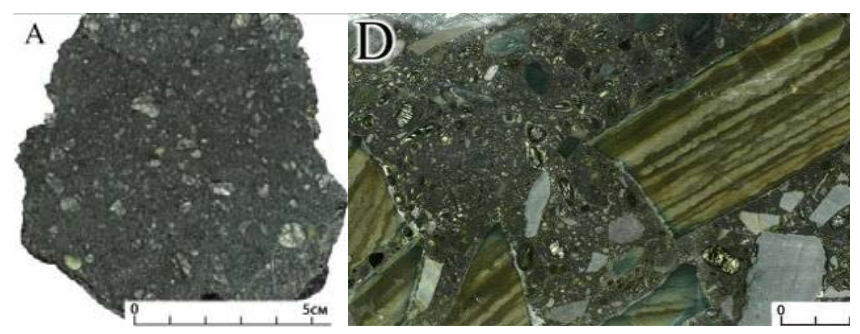

Fig. 1. Structure and texture differences of kimberlites. A- PK (Internatsionalnaya pipe), D- rich-xenolith KB (pipe

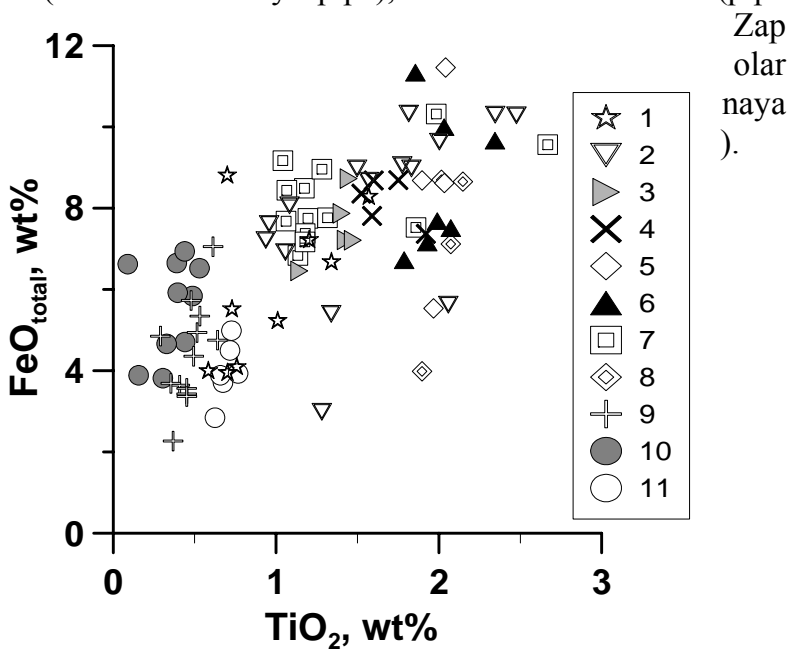

Fig. 2. Compositions of kimberlite from pipes: 1Yubileinaya, 2- Udachnaya-east, 3- Udachnaya-west, 4- Mir, 5- Komsomolskaya, 6- Zarnitsa, 7- Zapolarnaya, 8Sitykanskaya, 9- Aykhal, 10 - Internatsionalnaya, 11- 23 KPSS.

The petrochemical types of kimberlites were identified considering the abundance of major oxides $\left(\mathrm{FeO}, \mathrm{TiO}_{2}, \mathrm{~K}_{2} \mathrm{O}\right)$ 


\section{0th Intemational Kimberlite Conference-2012}

(Kostrovitsky et al., 2004). There are two petrochemical types of kimberlite within the diamondiferous fields of the Yakutian province: (1) magnesian, low-Ti, low-K (Mg-kimberlite) and (2) magnesian, high-Ti, low-K (Mg-Fe-kimberlite). The Aikhal, Internatsionalnaya, 23 KPSS and Udachnaya pipes are composed of Mg-kimberlites, whereas the Zarnitsa, Yubileinaya, Zapolarnaya and Mir pipes host Mg-Fekimberlites (Fig. 2).

\section{Mineralogy}

Olivine. Olivine is preserved in fresh kimberlites of pipes Udachnaya-east (20-65\% ol), Internatsionalnaya (ol 20$35 \%$ ), Zapolarnaya and Yubileinaya. Usually olivine is zonal, contains abundant ore mineral inclusions and rarely pyroxene and pyrope in rims (Fig. 3). As seen in the Fig. 4, olivines have complex zoning patterns.

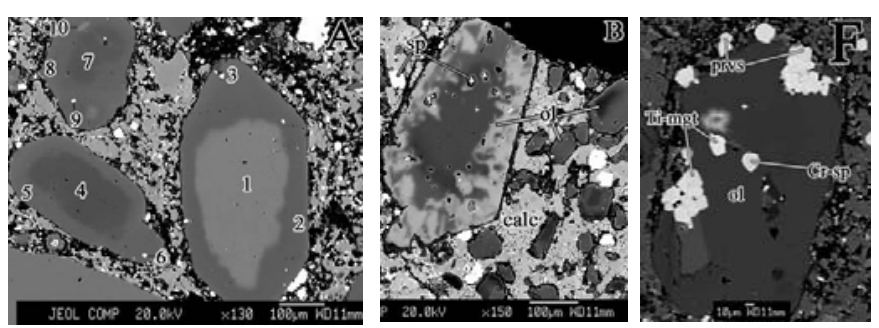

Fig. 3. Back-scattered electron (BSE) images of groundmass kimberlite from Udachnaya-east. A,B - zoned olivines (ol) from kiberlite: 1 - ol 85,3\%Fo, 2 - ol 88,8\%Fo, 4 - ol 90,5\%Fo, 5 - ol 88,9\%Fo, 7- ol 90\%Fo, 8 - ol 86,7\%Fo, $3-\mathrm{sp}, 6-\mathrm{sp}, 9-\mathrm{sp}, 10$ - pyrope. F-spinel (chromite and Timagnetite) inclusions in olivine and sp-prvs-ol aggregates.

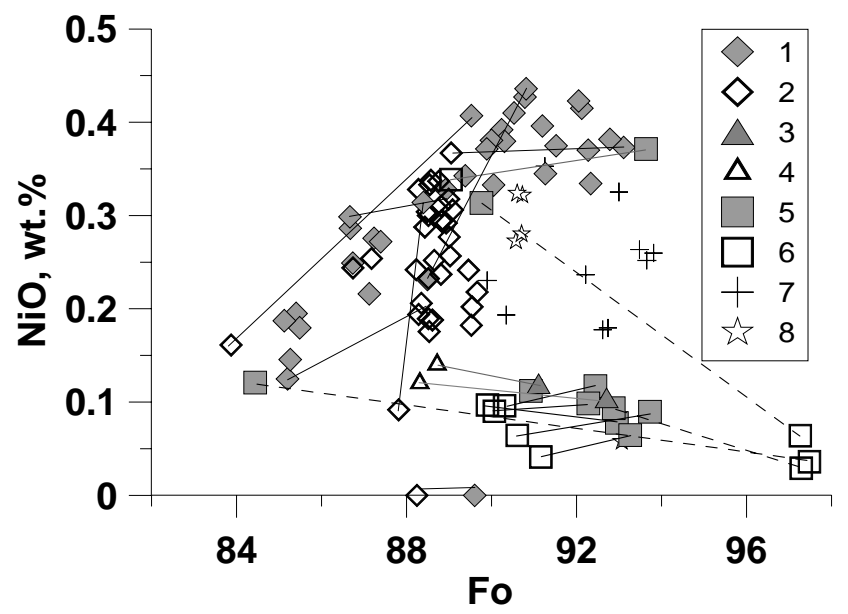

Fig. 4. Compositions of olivine: 1, 2-core and rim of phenocryst Udachnaya-east, 3,4 - core and rim of phenocryst Udachnaya-west, 5,6-core and rim of phenocryst Internatsionalnaya, 7-core of phenocryst Zapolarnaya, 8- core of phenocryst of Yubileinaya. Core and rim of some single grains are jointed by lines.

Magnesium-rich cores of phenocrysts with a high content of $\mathrm{NiO}(0.32-0.46 \mathrm{wt} \%)$ occur more frequently. Udachnaya-east zonal groundmass olivines differ from other: uniform Fo (86$90 \%$ ) in the rims, positive correlation between Fo and $\mathrm{NiO}$ in the core and weak negative correlation between $\mathrm{Fo}$ and $\mathrm{CaO}$ in the core. The lowest $\mathrm{NiO}$ in olivine of Internatsionalnaya and Udachnaya-west $(<0.1-0.2 \%)$ evidently indicates a significant metasomatic mineral processing, which occurred not just in the edge, but also in the central parts of grains.

Monticellite. Groundmass monticellite (mont) forms a small (up to $60 \mu \mathrm{m}$ ) idiomorphic and irregularly-shaped grains, and in places it forms clusters around olivine phenocrysts. A resorption of the rims is observed in the monticellite grains due to the late stage replacement by calcite and serpentinazation (Dawson, 1983, Mitchell, 1986). Monticellite was not found in KB. Zoning of monticellite looks as alternated concentric areas of varying ferrum coefficient (Fig. 5A).. Monticellite "pseudomorps" after olivine and diopside occurs rarely (Fig. 5B - 5, 6).
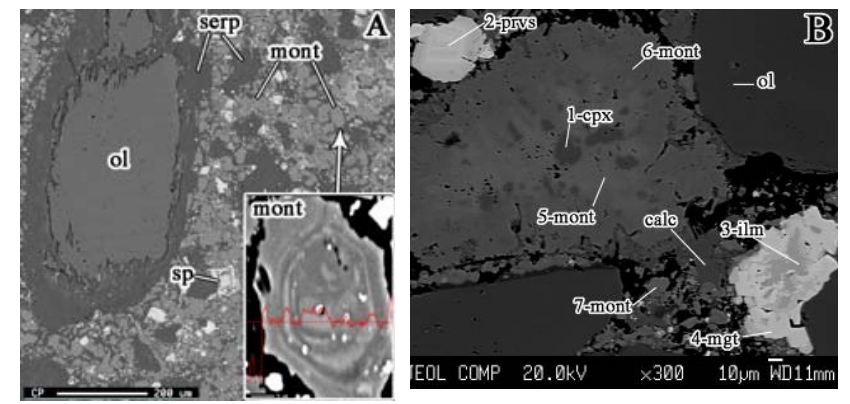

Fig. 5. BSE images of groundmass minerals in PK from pipe Zapolarnaya (A), aphanite kimberlite from pipe Ydachnaya-east (B). There is big zoned monticellite zoomed in the right bottom corner of image A.

Spinel. We have studied spinel of different paragenetic associations: the groundmass spinel; aggregates with ilmenite and perovskite; spinel inclusions in olivine, ilmenite, perovskite and phlogopite. Groundmass spinel usually occurs as euhedral zoned grains from 5 to $150 \mu \mathrm{m}$ (Fig. 6). Many pipes contain zoned and homogeneous spinel grains having an atoll rim with more abundant $\mathrm{Fe}$ and Ti. The gaps between the core and atolls are filled with carbonate and (or) serpentine. In the zoned spinel grains the central part is usually occupied by chromite; the intermediate zone is composed of ulvospinel or titanomagnetite; the rim is formed by titanomagnetite (Fig. 7). Al-spinel was detected in the titanomagnetite rims in the aphyric kimberlite of Udachnaya-east pipe at high density of monticellite and the complete absence of phlogopite in

\section{Extended Abstract}




\section{0th Intemational Kimberlite Conference-2012}

groundmass (Fig. 6D-pln). Virtually all zoned groundmass spinel belongs to the magnesium-ulvospinel-magnetite trend (MUM by Mitchell, 1986). Spinel of Mg-kimberlite is distinguished by higher chromium. Spinel from KB of many pipes hosts no ulvospinel and titanomagnetite. The spinel inclusions in olivine are factually high-chromium and magnesium chromites, rarely ulvospinel and Ti-magnetite. Spinel inclusions in perovskites of Zarnitsa pipe bear more magnesium and chromium than of spinel in ilmenite and phlogopite.
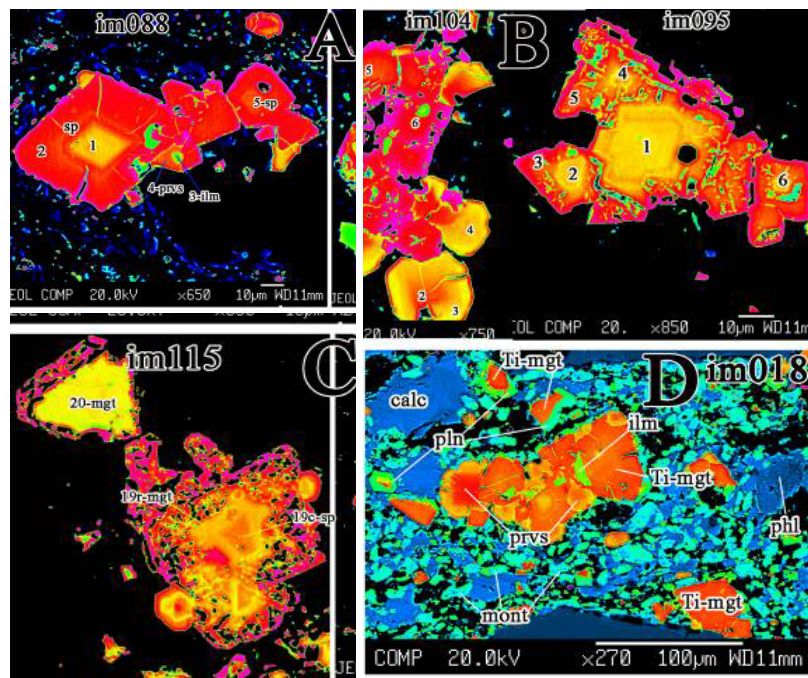

Fig. 6. Groundmass sp from pipe Ydachnaya-east (BSE images). A- PK, B- rich- xenolith $\mathrm{KB}, \mathrm{C}$ - poor-xenolith $\mathrm{KB}$, D- aphyric kimberlite.

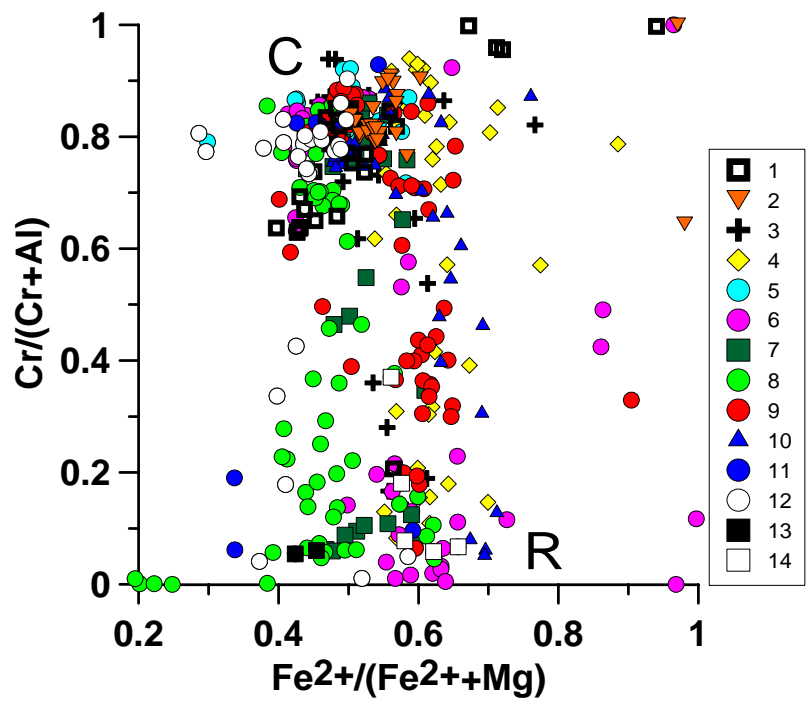

Fig. 7. Composition of groundmass spinel from kimberlite. 1- Sitykanskaya, 2 - 23 KPSS, 3- Komsomolskaya, 4- Mir, 5- Internatsionalnaya, 6- Zarnitsa, 7- Udachnaya-west, 8- Udachnaya-east, 9- Aykhal, 10- Yubileinaya, 11-
Zapolarnaya, 12- spinel inclusions in olivine (Internatsionalnaya, Udachnaya), 13- spinel inclusions in ilmenite and phlogopite (Zarnitsa), 14- spinel inclusions in perovskite (Zarnitsa). C-cores, R-rims.

Perovskite. Perovskite often occurs as aggregates with spinel, marking the co-crystallization (Fig. 8). Groundmass perovskite occurs mostly in PK. Perovskite from KB Sytykanskaya and Zarnitsa pipes differs from the rest by the skeletal forms of growth (Fig. 8B) and the presence of Timagnetite rims around perovskite. In Mg-kimberlites perovskite has not been detected. All studied perovskites are zoned. Content of LREE in perovskites are reduced mostly, and $\mathrm{CaO}$ increases from core to rim grains. Zoning can be cyclical in nature with rhythmic alternation of layers in respect of major oxides (Fig. 8B).
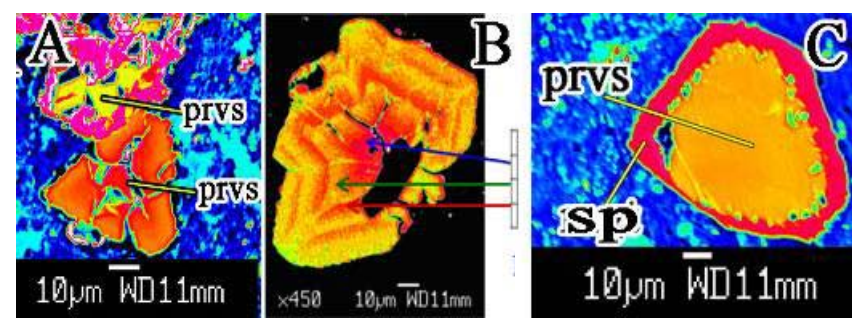

Fig. 8. Groundmass prvs in kimberlite Zarnitsa (BSE images). A- PK (in autholite), B- rich- xenolith $\mathrm{KB}, \mathrm{C}$ - poorxenolith KB.

Phlogopite. $\mathrm{Phl}$ is characterized by high $\mathrm{Mg}$, relatively high Ti, but low chromium. Phl rims with high content of $\mathrm{BaO}$ in the rims (3-12 wt.\%) occurs only in porphyry kimberlite in many explored pipes (Fig. 10A). Considering the $\mathrm{TiO}_{2}$ abundance the groundmass phlogopite can be divided into two groups (Fig. 9B): (I) low-Ti $\left(<2\right.$ wt.\% $\left.\mathrm{TiO}_{2}\right)$ and (II) high-Ti (from 2 to 4 wt.\% $\mathrm{TiO}_{2}$ ), basically corresponding to $\mathrm{Mg}$ and $\mathrm{Mg}-\mathrm{Fe}$ types of kimberlite

The zoned groundmass phlogopite is distinguished by increasing $\mathrm{BaO}$ and $\mathrm{Al}_{2} \mathrm{O}_{3}$ in the marginal parts, with slightly decreasing $\mathrm{TiO} 2, \mathrm{~K} 2 \mathrm{O}$ and $\mathrm{FeO}$. The central parts of phlogopite are generally more titaniferous and potassic than the rims.

Apatite. Groundmass apatite is more common in groundmass $\mathrm{KB}$ of Zarnitsa, Mir, Komsomolskaya pipes and in $\mathrm{Mg}$-kimberlites. In some kimberlites apatite gather round the older minerals (spinel, phlogopite, calcite), forms atolls and radial sprays of acicular crystals. Apatites from $\mathrm{Mg}$ kimberlites have the highest content of REE (up to $0.9 \mathrm{wt} . \%$ $\mathrm{Ce}_{2} \mathrm{O}_{3}$, up to $0.6 \mathrm{La}_{2} \mathrm{O}_{3}$, as well as lower fluorine content.

Calcite. Groundmass calcite forms small xenomorphic grains, in places together with serpentine it is involved in the pseudomorphs after olivine and rarely forms "microliths"

\section{Extended Abstract}

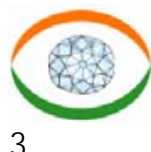




\section{0th Intemational Kimberlite Conference-2012}

(primary prismatic flow-aligned crystals (Mitchell, 1986). The distribution of calcite in groundmass is extremely irregular within any kimberlite pipe (Fig. 10). Calcite "microliths" are widespread in Mg-kimberlites, and in some kimberlites they produce the flow structure (23 KPSS and Zarnitsa pipes). The groundmass calcite displays wide content variations of trace elements, e.g. $\mathrm{Sr}$ and $\mathrm{Ba}$. The highest concentrations of these elements are measured in calcite "microliths" ( $\mathrm{BaO}$ up to 0.16 $\mathrm{wt} \%$ and $\mathrm{SrO}$ up to $0.98 \mathrm{wt} \%$ ) indicating their magmatic origin. Groundmass dolomite occurs in addition to the dominant calcite. In poorly-serpentinized PK of Internatsionalnaya and Mir pipes carbonate was found with $\mathrm{MgO}$ reaching $21 \mathrm{wt} . \%$. In $\mathrm{KB}$ the $\mathrm{MgO}$ content in the calcite is about $2 \mathrm{wt} . \%$.
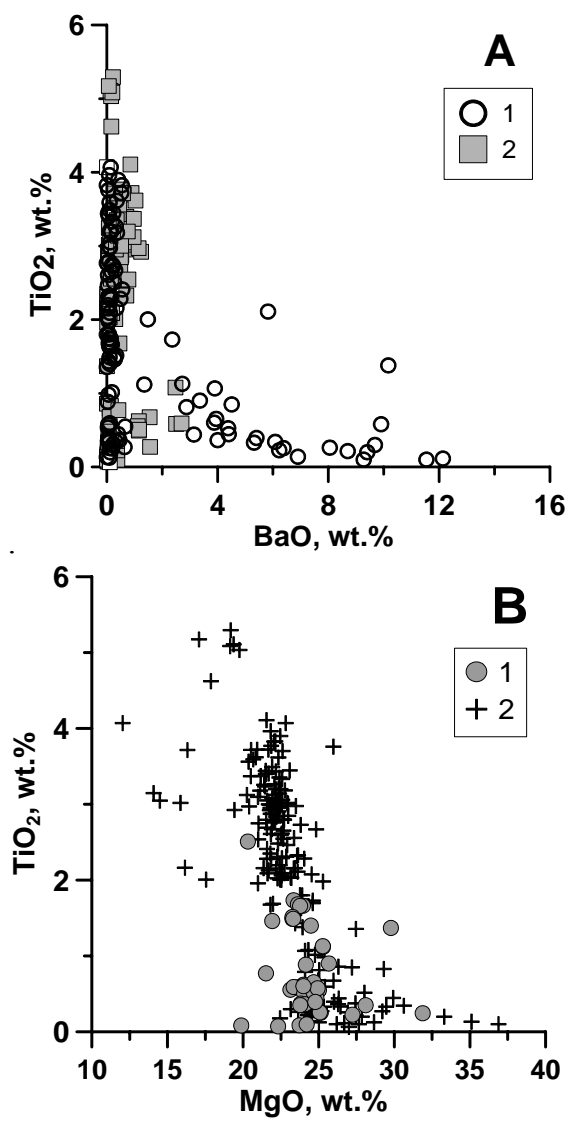

Рис. 9. Composition of groundmass phl. А: 1- PK, 2- KB. В: 1- Mg-kimberlite, 2- Mg-Fe-kimberlite.

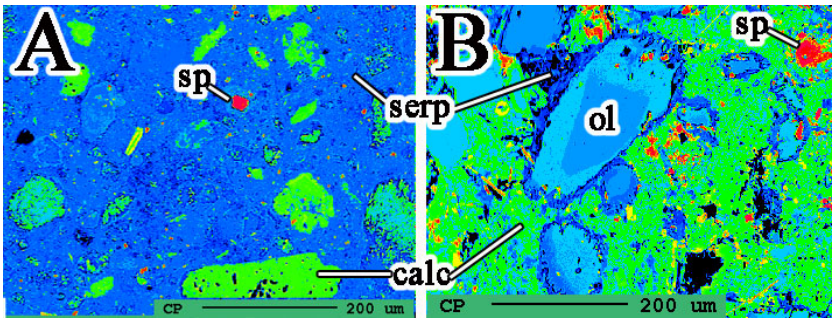

Fig. 10. Back-scattered electron images of Internatsionalnaya. A - PK; B - rich-xenolith KB.

\section{Conclusions}

Composition of groundmass minerals and their chemistry is related to petrochemical type kimberlites and depends on the structural and textural features of rocks, as well as the intensity of secondary processes. In the magnesian kimberlite groundmass there are high contents of primary calcite, high-Cr spinel, low-Ti phlogopite and LREE-enriched apatite, as well as extremely low picroilmenite and totally lacking perovskite. The $\mathrm{Mg}$-Fe kimberlites are marked by widespread picroilmenite, Ti-magnetite, perovskite (including magnetite and perovskite aggregates) and high-Ti phlogopite. There are significant differences in the compositions of groundmass minerals from different structural and textural types of kimberlite. The groundmass of kimberlite breccia is featured by: high-Cr low-Ti spinel domination, mostly common for atoll structures, and possible skeletal perovskite growth. The porphyritic kimberlites typically incorporate zonal spinel, more Fo spinel cores (in comparison with spinel of kimberlite breccia) and high-BaO phlogopite in the rims.

The formation of groundmass get started with crystallization of euhedral olivine, phlogopite and spinel at $\mathrm{P}=1.0 \mathrm{GPa}$ and $\mathrm{T}=1030-1170^{\circ} \mathrm{C}$ (Fedortchouk et al., 2004) and was completed by low-temperature serpentine and magnetite recrystallization.It is noteworthy, that most of groundmass minerals are characterized by wide composition variations, zoning, local heterogeneity, grain resorption and deuteric replacement. Different composition of groundmass olivine cores is possibly due to the heterogeneous composition of the primary kimberlite melt.

Different composition of groundmass olivine core is possibly due to the heterogeneous composition of the primary kimberlite melt (Reid et al., 1975; Boyd \& Clement, 1977; Skinner, 1989; Kamenetsky et al., 2007; Mitchell, 2008; Brett et al., 2009). The marginal parts of olivine rims with constant Fo have crystallized in a relatively narrow temperature range at the constant ratio of $\mathrm{Mg} / \mathrm{Fe}$ in the melt-fluid saturated with olivine and carbonate (Mitchell, 1986; Kamenetsky et al., 2007) or have formed under the metasomatic effect of residual kimberlite melt on the olivine phenocrysts at the final stage of kimberlite emplacement (Kostrovitsky, 1986). Very low

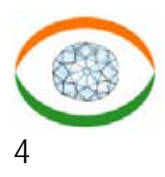




\section{0th Intemational Kimberlite Conference-2012}

content of $\mathrm{NiO}$ in olivine $(<0.1-0.2 \%)$ is possibly an evidence of significant metasomatic processes, which procceded deeper than in the grain rims. The uncommon inclusions of low-Cr high-Ti spinel in groundmass olivine rims (Udachnaya-east, Internatsionalnaya), as well as ol-prvs-sp aggregates indicate the olivine crystallization under near-surface conditions.

The inclusions of diopside in monticellite are interesting in terms of mutual exclusion of monticellite and diopside in kimberlites (Mitchell, 1998). Importantly, that the groundmass spinel composition ranges widely from chromite to pleonaste.

Importantly, that the groundmass spinel composition ranges widely from chromite to pleonaste. The atoll-spinel formation is still debatable (Reid et al., 1975, Mitchell \& Clark, 1976, Agee et al., 1982, Pasteris, 1983, Armstrong et al., 1997, O'Brien et al., 1999. The atoll spinel is mostly typical for $\mathrm{KB}$ (Fig. $6 \mathrm{~B}, \mathrm{C}$ ) and uncommon for massive porphyry varieties (Fig. 6A, D). Quite the contrary, zoned spinel is much more common in PK, whereas ulvoshpinel and Ti-magnetite prevail in the rims. Thus, the xenolith-rich country rock in kimberlite melt was capable to promote spinel rapid growth, which is confirmed by the lack of Ti-rich, Crpoor varieties of spinel in KB. In any case, the complex atoll rim formation is due to a combination of factors that mainly result from the rapidly changing conditions being far from equilibrium.

The oxygen fugacity ( $f \mathrm{O} 2$ ) during the emplacement of kimberlites was estimated from the $\mathrm{Fe}$ and $\mathrm{Nb}$ contents in perovskite (Bellis \& Canil, 2006). Some kimberlites show that higher $\mathrm{fO} 2$ values correlate with lower diamondiferous.

The high-BaO (3-12 wt.\%) in phlogopite rims is common only for PK, where the country rock xenoliths are absent. This fact indicates that the $\mathrm{BaO}$ source is not associated with assimilation of carbonate host rocks. So, it can be assumed that growth of barium rims is associated with groundmass calcite recrystallization, with hot fluids effect involved. There is a positive correlation between groundmass apatite and calcite content in kimberlite. It is believed that apatite precipitates from the melt simultaneously with calcite (Mitchell, 1986)

\section{References}

Agee, I.I., Garrison, I.R., (1982). Petrogenesis of oxide minerals in kimberlite, Elliott County, Kentucky//Amer. Miner. v.67. p. 28-42.

Armstrong, J.P., Wilson, M., Barnett, R.L., Nowicki, T., Kjarsgaard, B.A., (2004). Mineralogy of primary carbonate-bearing hypabyssal kimberlite, Lac de Gras, Slave Province, Northwest Territories, Canada. Lithos 76, 415-433.

Blagulkina, V.A., Taranovskaya, A.N. (1975). About perovskite from kimberlites of Yakutia, Zap. WMO, Part 104, Vol. 6, 703-710 (in Russian).
Boctor, B.Z., Boyd, F.R. (1979). Oxide minerals in the Lighobong kimberlite, Lesoto // Am. Miner. V.65. p.631-638.

Boyd, F. R. \& Clement, C. R. (1977). Compositional zoning of olivines in kimberlites from the De Beers mine, Kimberley, South Africa. Carnegie Institution of Washington Yearbook 76, 485-493.

Bovkun, A.V., Serov, I.V., Garanin, V.K., Kudryavtseva, G.P. (1999). Microcrystall oxide minerals from groundmass kimberlites as an indicator of the evolution of kimberlite melts and diamond / / Experiment of Geosciences, - M, 16-17 (in Russian).

Brett, R.C., Russell, J.K. and Moss, S.W. (2009). Origins of Olivine in Kimberlite: Phenocryst or Impostor?: Lithos, Vol. 112 (S1) pp. 201-212.

Dawson, J. B. (1980). Kimberlites and their Xenoliths. Berlin: Springer.

Egorov, K.N., Bogdanov, G.V. (1991). Monticellite from kimberlites of Yakutia / / ZVMO, № 2, 78-87 (in Russian).

Fedortchouk, Y. \& Canil, D. (2004). Intensive variables in kimberlite magmas, Lac de Gras, Canada and implications for diamond survival. Journal of Petrology 45, 1725-1745.

Garanin, V.K., Kudryavtseva, G.P., Soshkina, L.T. (1984). Ilmenite from kimberlites. M.: MGU, $240 \mathrm{p}$ (in Russian).

Garanin, V.K., Bovkun, A.V., Garanin, K.V., Rothman, A.J., Serov, I.V. (2009). Microcrystall oxides from kimberlites of Russia. M.: GEOS, 498 p (in Russian).

Haggerty, S.E. (1976). Opaque mineral oxides in terrestrial igneous roks.// D.Rumble, Ed.Oxides MineraIs.Short Course Notes, Mineralogical Society of America. Washington.D.C. p. 101-300.

Kornilova, V.P., Egorov, K.N., Safronov, A.F., Filipov, N.D., Zaitsev, A.I. (1998). Monticellite kimberlite from pipe Udachnaya and some aspects of the kimberlite melts evolution // Otechestvennaya geology. № 6. S. 48-51.

Kostrovitsky, S.I. (1986). Geochemical features of minerals of kimberlites. Novosibirsk: Nauka, 263 p (in Russian).

Kostrovitsky, S.I., Morikio, T., Serov, I.V., Rothman, A.Ya. (2004). About origin of kimberlite. Doklady. T. 399. № 2. S.

Mitchell, R.H. (1986). Kimberlites: their mineralogy, geochemistry and petrology. New York, $436 \mathrm{p}$.

Mitchell, R.H. (2008). Petrology of hypabyssal kimberlites: relevance to primary magma

compositions. Jour Volc Geoth Res doi:10.1016/j. jvolgeores.2007.12.024

Moore, A. E. (1988). Olivine: a monitor of magma evolutionary paths in kimberlites and olivine melilitites. Contributions to Mineralogy and Petrology 99, 238-248.

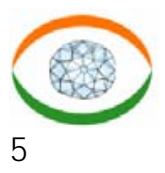


10't Intemational Kimberlite Conference-2012

Roeder, P.L., Schulze, D.J. (2008). Crystallization of

groundmass spinel in kimberlite. Journal of Petrology, v. 49,

1473-1495.

Extended Abstract 